\title{
ЭКОЛОГИЯ
}

И ПРИРОДОПОЛЬЗОВАНИЕ

DOI: https://doi.org/10.15688/nsr.jvolsu.2019.4.6

UDC 574.5

LBC 28.680

\section{ASSESSMENT OF THE STATE OF VOLGA-AKHTUBA FLOODPLAIN WATER RESERVOIRS BY VARIOUS INDICES OF ZOOBENTHOS IN THE CONDITIONS OF THE GROWING SEASON OF 2018}

\author{
Angelina M. Schukina \\ Volgograd State University, Volgograd, Russian Federation; \\ Volgograd branch of Russian Federal Research Institute of Fisheriesand Oceanography, \\ Volgograd, Russian Federation \\ Vladimir P. Gorelov \\ Volgograd branch of Russian Federal Research Institute of Fisheriesand Oceanography, \\ Volgograd, Russian Federation
}

Tatjana E. Zenkina

LLC "Volgogradnefteproekt", Volgograd, Russian Federation; Volgograd State University, Volgograd, Russian Federation

\begin{abstract}
The conducted research allows to evaluatethe ecological and biological status of waterbodies of the Volga-Akhtuba floodplain on the structural characteristics of pentosanase, which is the basis for further research. When conducting biological research of any nature, it is always important to know what species and in 2 what quantityare part of this natural community. This allows to reflect the state of the ecosystem better and obtain $\underset{\sim}{\vec{\delta}}$ objective materials from which long-term changes taking place in itcan be observed. Zoobenthos is one of the most important elements of the ecosystems of continental water bodies and streams. In the course of the work, 12 reservoirs $\rightarrow-$ have been investigated and 72 hydrological samples processed. To assess the state of the water bodies of the 좊 Volga-Akhtuba floodplain, the authors have used such indicators as: abundance, biomass, species richness (number of species) and have calculated Shannon index, Shannon evenness index, and Simpson dominance index. Based on $\stackrel{m}{m}$ the ranked values of the obtained indicators, five-point scales have been compiled for the assessment of water $\therefore$ bodies. On the basis of the obtained data, a five-point scale has been developed to simplify the assessment of the m state of the Volga-Akhtuba floodplain. Scores for this work were built separately for each season. This is due to the \% fact that the overall score scale distorts the gradation of indicators and gives an insufficiently correct assessment. 2. Analysis and visualization of data has been carried out using the programming language R, which is used for statistical data processing and graphics. The $\mathrm{R}$ language is a free open-source computing environment that $\dot{\sum}$ implements the most advanced data analysis methods. Environment R is the most versatile biodiversity analysis $<$ software. Using this language, the indicators have been calculated, as well as their graphic processing of the obtained values. On the basis of the obtained data and compiled point scales, the authors present the assessment of water bodies by seasons.
\end{abstract}

Key words: zoobenthos, water bodies of the Volga-Akhtuba floodplain, anthropogenic impact, hydrobiological (2) monitoring, indicators, assessment of the state of water bodies. 


\title{
ОЦЕНКА СОСТОЯНИЯ ВОДОЕМОВ ВОЛГО-АХТУБИНСКОЙ ПОЙМЫ ПО РАЗЛИЧНЫМ ПОКАЗАТЕЛЯМ ЗООБЕНТОСА В УСЛОВИЯХ ВЕГЕТАЦИОННОГО ПЕРИОДА 2018 ГОДА
}

\author{
Ангелина Михайловна Щукина \\ Волгоградский государственный университет, г. Волгоград, Российская Федерация; \\ Волгоградский филиал Всероссийского научно-исследовательского института рыбного хозяйства \\ и океанографии, г. Волгоград, Российская Федерация

\section{Владимир Павлович Горелов} \\ Волгоградский филиал Всероссийского научно-исследовательского института рыбного хозяйства \\ и океанографии, г. Волгоград, Российская Федерация
}

\section{Татьяна Евгеньевна Зенкина}

ООО «Волгограднефтепроект», г. Волгоград, Российская Федерация; Волгоградский государственный университет, г. Волгоград, Российская Федерация

Аннотация. В статье приводятся результаты исследования зообентоса некоторых водоемов Волго-Ахтубинской поймы. Проведенное исследование позволяет оценить эколого-биологическое состояние водных объектов Волго-Ахтубинской поймы по структурным характеристикам донных биоценозов. На основе полученных данных, с помощью базовой конфигурации R, разработана пятибалльная шкала для упрощения оценки состояния водоемов Волго-Ахтубинской поймы. На основе полученных данных и составленных балльных шкал ряда показателей дана оценка состояния водных объектов по сезонам года.

Ключевые слова: зообентос, водоемы Волго-Ахтубинской поймы, антропогенное воздействие, гидробиологический мониторинг, показатели, оценка состояния водных объектов.

Введение. Волго-Ахтубинская пойма является крупнейшей в мире речной долиной и обладает значительными природными богатствами. В суровых, засушливых условиях резко континентального климата пойма формировалась много тысячелетий. Водоемы Волго-Ахтубинской поймы периодически страдают от антропогенного воздействия [5]. До строительства Волжской ГЭС почти вся поверхность Волго-Ахтубинской поймы ежегодно заливалась волжскими водами. В настоящее время величина весеннего половодья регулируется работой Волжской ГЭС, и поэтому в маловодные годы не все водоемы заливаются достаточным количеством вод и зачастую обсыхают полностью, приводя к гибели биоценозов водных организмов [2-3]. В Волго-Ахтубинской пойме проводилось ряд исследований, посвященные биоразнообразию и пространственному распределению водных организмов, в том чис- ле. макрозообентоса, так же бентос изучался как кормовая база, интенсивности развития и продукции зообентоса водоемов поймы $[6 ; 7 ; 15]$. При проведении биологических исследований любого характера, всегда важно знать какие виды, и в каком количестве входят в состав данного природного сообщества. Это позволяет более полно отразить состояние экосистемы и получить объективные материалы, по которым можно наблюдать долговременные изменения, протекающие в ней $[8 ; 10 ; 12]$. Зообентос один из важнейших элементов экосистем континентальных водоемов и водотоков. Сообщества зообентоса, являясь чувствительными индикаторами состояния водных объектов, широко используются для биоиндикации $[1 ; 11]$.

Объект данного исследования: водоемы Волго-Ахтубинской поймы.

Целью работы является попытка оценить эколого-биологического состояния водо- 


\section{ЭКОЛОГИЯ И ПРИРОДОПОЛЬЗОВАНИЕ}

емов Волго-Ахтубинской поймы по структурным характеристикам бентоценоза.

Материалы и методы. Материалами исследования послужили гидробиологические сборы, выполненные в 2018 году на водоемах Волго-Ахтубинской поймы в сезонном аспекте.

Среднеахтубинский район в данном исследовании представлен пятью водоемами: оз. Широкогорлое, оз. Большая Невидимка, ер. Гнилой, оз. Запорное, оз. Дегтярное. В Ленинском районе пробы отбирались на семи водоемах: оз. Боярский лиман, оз. Бессчастное, ер. Старая Ахтуба, оз. Кудаевское, оз. Чичера, оз. Дубок, ер. Калинов.

Для идентификации донных беспозвоночных использовались определители Европейской части СССР и сопредельных территорий России $[16 ; 17 ; 18 ; 19 ; 21]$.

Для оценки состояния водоемов ВолгоАхтубинской поймы использовались такие показатели, как: численность, биомасса, видовое богатство (количество видов) и рассчитывались: индекс Шеннона, показатель выравненности по Шеннону, индекс доминирования по Симпсону. На основе ранжированных значений полученных показателей были составлены пятибалльные шкалы для оценки водоемов.

Вышеуказанные показатели вычислялись в каждом водоеме для каждого зообентоценоза по трем сезонам. Далее полученным значениям показателей присваивались баллы согласно оценочным шкалам от 1 до 5 баллов, затем просчитывалось суммарное количество баллов для водоема.

Анализ и визуализация данных проводились с помощью языка программирования $\mathrm{R}$, используемого для статистической обработки данных и работы с графикой [14]. С помощью данного языка были проведены вычисления показателей, а также их графическая обработка полученных значений.

Результаты исследования. За период наших исследований было отобрано 72 гидробиологические пробы, из них 24 пробы весенние, 24 летние и 24 осенние. В изученных водоемах было выявлено 159 таксонов организмов зообентоса, которые принято искусственно разделять на основные, имеющие главное значение в количественных показателях, и прочие, не играющие роль в основных пока- зателях. Из них: 35 видов личинок комаровзвонцов (Chironomidae), 22 вида малощетинковых червей (Oligochaeta), 30 видов брюхоногих и двустворчатых моллюсков (Mollusca), 14 видов ракообразных (Crustacea) и 58 видов организмов группы прочих (Hirudinea, Odonata, Ephemeroptera, Megalopteran, Lepidoptera, Coleoptera, Acariformes, Trichoptera, Diptera (Ceratopogonidae), Hemiptera).

Для визуализации полученных данных использовались категоризованные графики, демонстрирующие значения численности организмов зообентоса, которые разбиваются на отдельные категории (сезоны и водоемы). Для удобства восприятия информации, водоемы разделены по географической принадлежности на Среднеахтубинский район (см. рис. 1) и Ленинский район (см. рис. 2).

На графиках, иллюстрирующих водоемы Среднеахтубинского района хорошо заметны пики численности основных групп зообентоса в разные периоды. Так, доминирующими по численности группами являются Chironomidae и Oligochaeta, в некоторых случаях преобладают организмы группы прочих (см. рис. 1).

Графики, построенные по показателям водоемов Ленинского района, так же демонстрируют преобладание Chironomidae и Oligochaeta. Численность данных организмов невысокая и меньше подвергается колебаниям, в отличии от водоемов Среднеахтубинского района (см. рис. 2). Это может быть связано с тем, что Ленинский район относится к низкой пойме и имеет относительно стабильную структуру, не подвергается сильному антропогенному воздействию от гидрологического режима Волжской ГЭС, в отличие от Среднеахтубинского района, высокой поймы.

Численность организмов зообентоса за весенний сезон колебалась в интервалах от 282 до 7520 экз $/ \mathrm{M}^{2}$; за летний сезон от 674 до 4291 экз/м²; за осенний сезон от 502 до 6848 экз м². Доминирующими по численности группами в течении сезона в большинстве водоемов являлись Chironomidae и Oligochaeta, в некоторых водоемах, заросших макрофитовыми зарослями, преобладают организмы группы прочих, например, в оз. Дегтярное 
(рис. 1). В весенний период, особенно в его начале, для бентоса пойменных водоемов характерны максимальные значения количественных показателей. Затем происходит падение численности и биомассы донной фауны, связанное, по всей видимости, с завершением цикла развития у гомотопных организмов и вылетом имаго гетеротопных. В дальнейшем показатели численности вновь возрастают (см. рис. $3 a$ ).

Биомассу организмов зообентоса обычно разделяют на мягкий бентос, куда входят все организмы зообентоса, кроме моллюсков, и общий бентос, представляет собой сумму всех организмов с моллюсками.

Весенние показатели биомассы обследованных нами водоемах колеблются в ши- роких интервалах от 1,228 до 30,88 г/ $^{2}$. Наибольшее значение биомассы представлено в оз. Кудаевское, наименьшее в ер. Калинов (см. рис. $3 b$ ).

Биомасса мягкого бентоса летнего сезона находится в интервалах от 0,848 до 7,477 г/м². Максимальное значение биомассы имеет ер. Гнилой, а минимальное оз. Дубок. Летом происходит непрерывное уменьшение численности и биомассы, вызванное с одной стороны интенсивным питанием рыбы организмами, а с другой их цикличностью развития (см. рис. $3 b$ ).

Осенью размах колебаний биомассы от

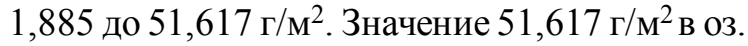
Дегтярное, является максимальным, что по-

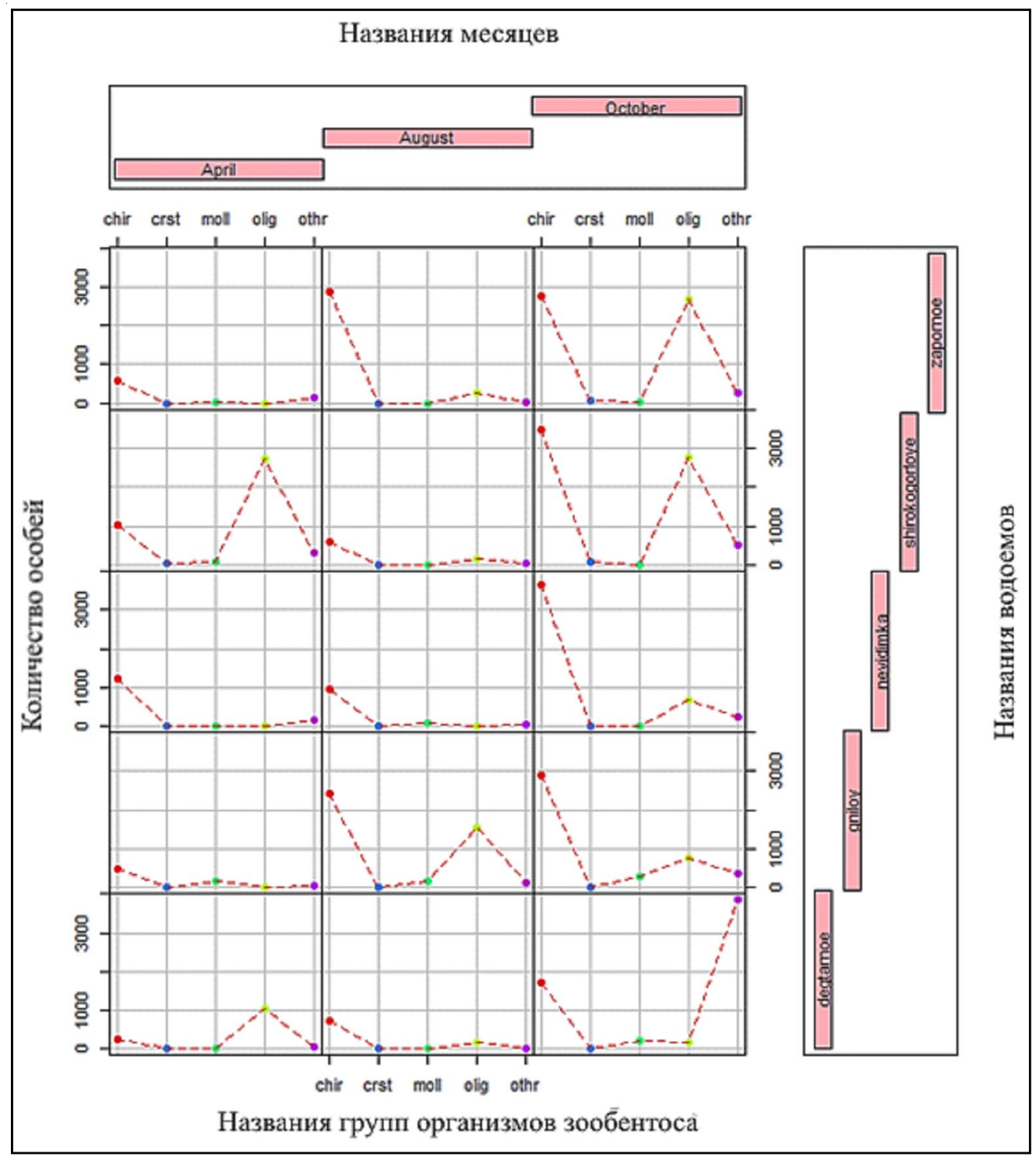

Рис. 1. Категоризованный график численности основных групп организмов зообентоса Среднеахтубинского района поймы (chir-chironomidae, crst-crustacea, moll-mollusca, olig-oligohaeta, othr-nрочue) 


\section{ЭКОЛОГИЯ И ПРИРОДОПОЛЬЗОВАНИЕ}

казано как выброс (см. рис. $3 b$ ). А минимальное значение характерно для оз. Бессчастное. С августа и до конца вегетации количественные показатели снова возрастают.

Видовое богатство представляет собой число таксонов живых организмов, обитающих в данном сообществе, отражающее биологическое разнообразие и качественный состав. Это простой показатель, демонстрирующий таксономическое богатство. Количество видов весеннего сезона находится в интервале от 4 до 26, летнего сезона от 10 до 20, а осеннего от 12 до 34 видов (см. рис. $3 c$ ). Видовое богатство осеннего сезона больше, чем весной и летом, это может быть связано с тем, что пробы отбираются после зимнего периода, когда видовое разнообразие организ- мов черезвычайно мало, кроме того половозрелая часть малощетинковых червей элиминирует. А к осени, после паводка и теплого лета организмы зообентоса активно размножаются.

В экосистемах для анализа структуры биоценозов широко применяется индекс доминирования Симпсона [22]. Большинство исследователей на сегодня считают оптимальным для оценки видового разнообразия индекс Шеннона [23]. Индекс выровненности по Шеннону один из популярных показателей организационной структуры сообщества, демонстрирующий относительное распределение особей среди видов [22]. В таблице 1 представлены значения индексов в виде интервала за три месяца.

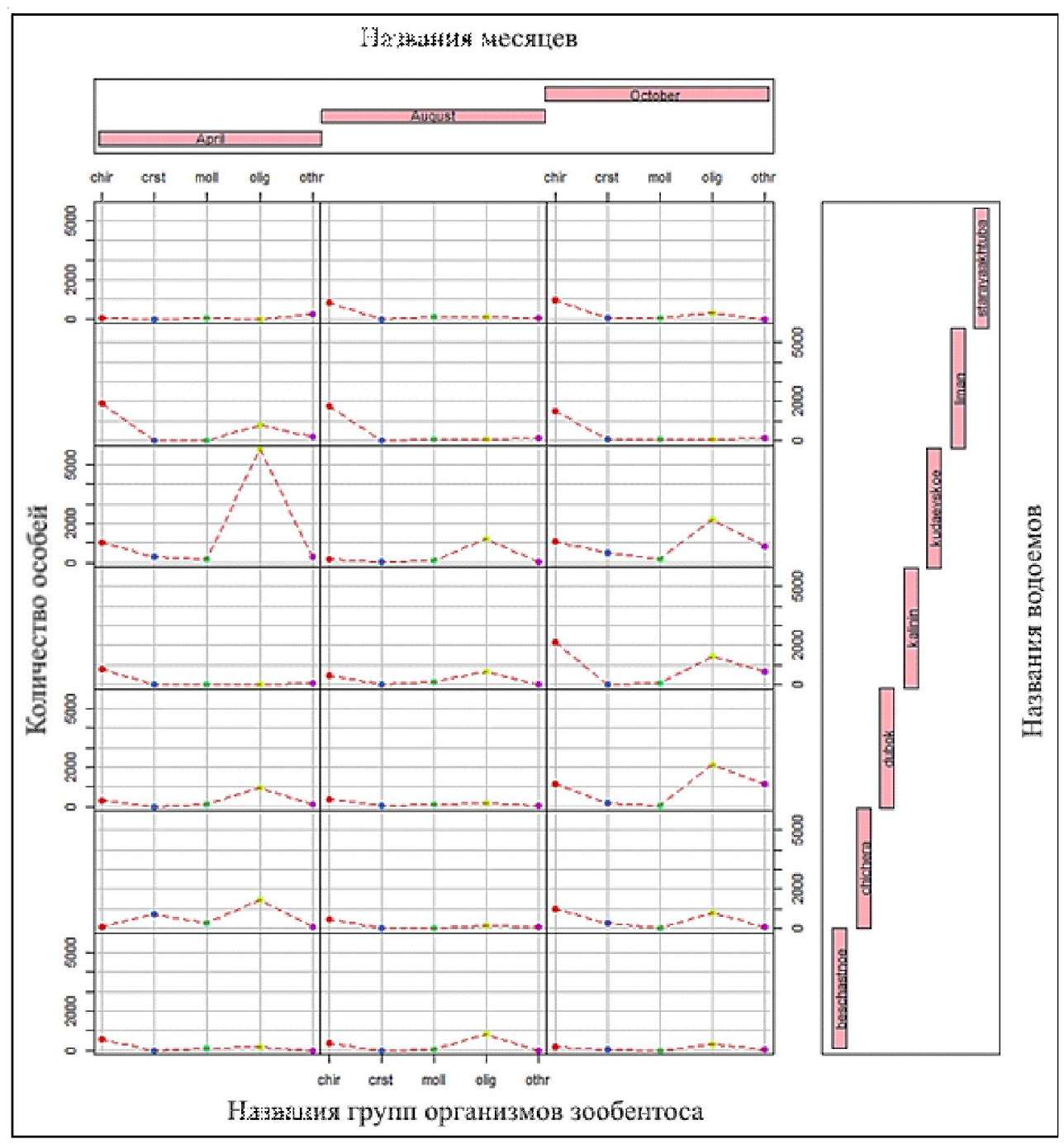

Рис. 2. Категоризованный график численности основных групп организмов зообентоса Ленинского района поймы (chir-chironomidae, crst-crustacea, moll-mollusca, olig-oligohaeta, othr-npoчue) 
Оценка состояния водоемов поймы по различным показателям зообентоса

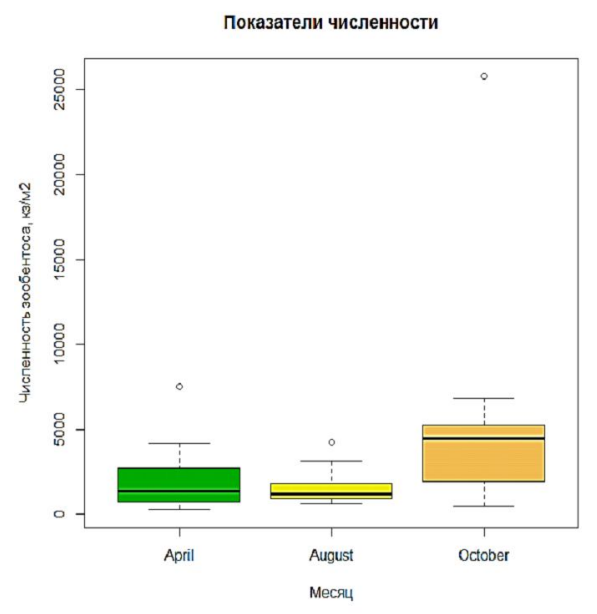

а) Численность организмов зообентоса

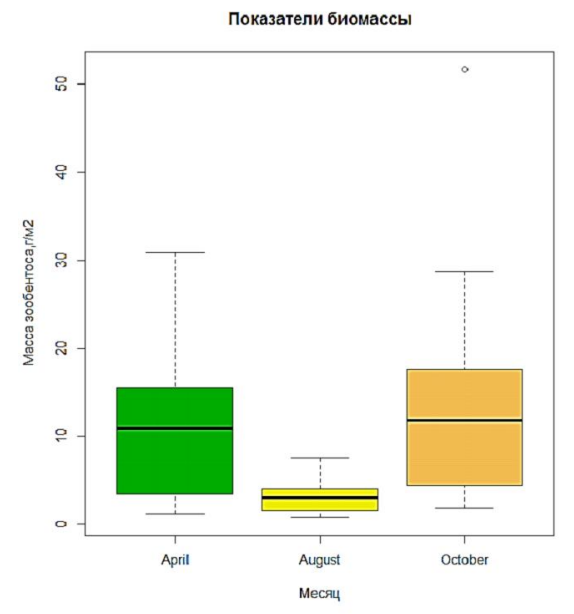

b) Биомасса организмов зообентоса

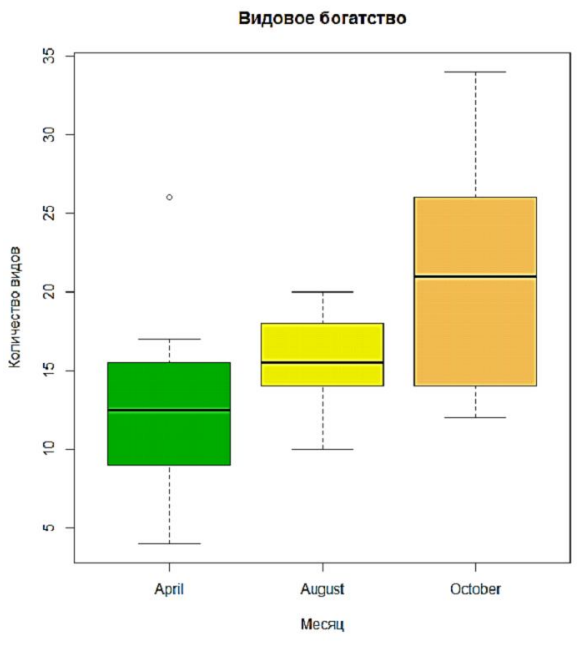

c) Видовое богатство

Рис. 3. Диаграммы размахов численности, биомассы и видового богатства организмов зообентоса

Интервалы значений индексов по зообентосу водоемов Волго-Ахтубинской поймы за 2018 год

\begin{tabular}{|l|c|c|c|}
\hline \multicolumn{1}{|c|}{ Водный объект } & $\begin{array}{c}\text { Индекс } \\
\text { видового } \\
\text { разнообразия } \\
\text { Шеннона }\end{array}$ & $\begin{array}{c}\text { Индекс выровненности } \\
\text { по Шеннону }\end{array}$ & $\begin{array}{c}\text { Индекс } \\
\text { доминирования } \\
\text { Симпсона }\end{array}$ \\
\hline Озеро Бессчастное & $0,955-2,119$ & $0,556-0,803$ & $0,833-0,508$ \\
\hline Озеро Чичера & $1,269-2,301$ & $0,529-0,851$ & $0,883-0,611$ \\
\hline Озеро Дубок & $2,234-2,713$ & $0,877-0,825$ & $0,909-0,853$ \\
\hline Озеро Боярский лиман & $1,817-2,111$ & $0,689-0,808$ & $0,839-0,719$ \\
\hline Ерик Калинов & $1,395-2,253$ & $0,671-0,856$ & $0,893-0,665$ \\
\hline Озеро Кудаевское & $1,138-2,647$ & $0,431-0,812$ & $0,902-0,426$ \\
\hline Ерик Старая Ахтуба & $1,332-2,111$ & $0,641-0,849$ & $0,861-0,608$ \\
\hline Ерик Гнилой & $2,090-2,655$ & $0,716-0,847$ & $0,911-0,829$ \\
\hline Озеро Дегтяное & $2,199-1,346$ & $0,776-0,503$ & $0,847-0,585$ \\
\hline Озеро Запорное & $2,075-2,341$ & $0,866-0,739$ & $0,864-0,849$ \\
\hline Озеро Большая & $1,683-2,299$ & $0,621-0,871$ & $0,875-0,706$ \\
\hline Невидимка & $1,826-2,582$ & $0,561-0,812$ & $0,904-0,644$ \\
\hline Озеро Широкогорлое & & \\
\hline
\end{tabular}




\section{ЭКОЛОГИЯ И ПРИРОДОПОЛЬЗОВАНИЕ}

Наибольшие значения индекса Шеннона характерны для оз. Большая Невидимка, Запорное и Дубок. Индекс доминирования Симпсона имеет схожие значения с индексом выравненности по Шеннону и не имеют значительных разбросов показателей. Максимальные значения встречаются в озере Большая Невидимка и ерике Гнилой, минимальные в озере Кудаевское (рис. 4).

Для разработки пятибалльной шкалы использовались диаграммы размаха (боксплоты). Графики этого типа позволяют дать полную статистическую характеристику анализируемой совокупности. Боксплот состоит из нижнего уса (минимальное значение), нижнего квартиля, медианы, верхнего квартиля и верхнего уса (максимальное зна-

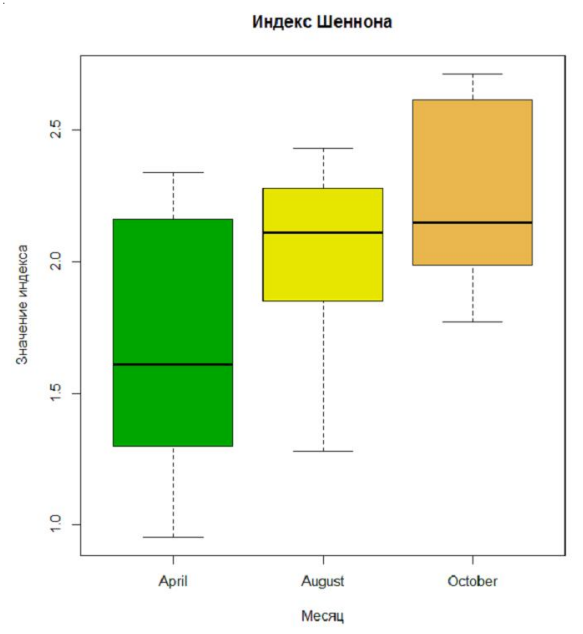

а) Индекс Шеннона чение). На основании проведенных вычислений, полученные показатели были проранжированы и сведены в единую таблицу (см. табл. 2). Предлагаемые нами шкалы рекомендованы для оценки состояния водоемов поймы.

На основе полученных данных и составленных балльных шкал, была дана оценка водоемам по сезонам, где: 1 балл - предельно низкое значение, 2 балла - низкое значение, 3 - среднее, 4 - выше среднего, 5 баллов нормальное. Баллы по каждым показателями суммируются и образуют суммарную балльную оценку за сезон, затем баллы по сезонам также суммируются, показывая итоговую оценку по водоемам за вегетационный период (см. табл. 3).

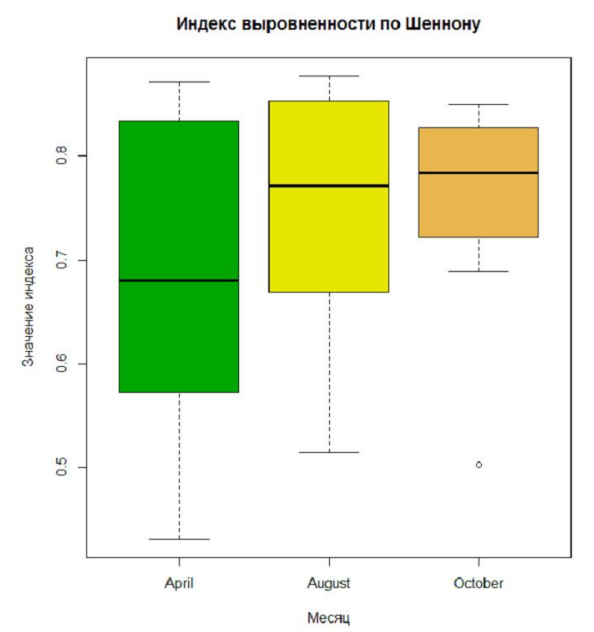

b) Индекс выровненности по Шеннону

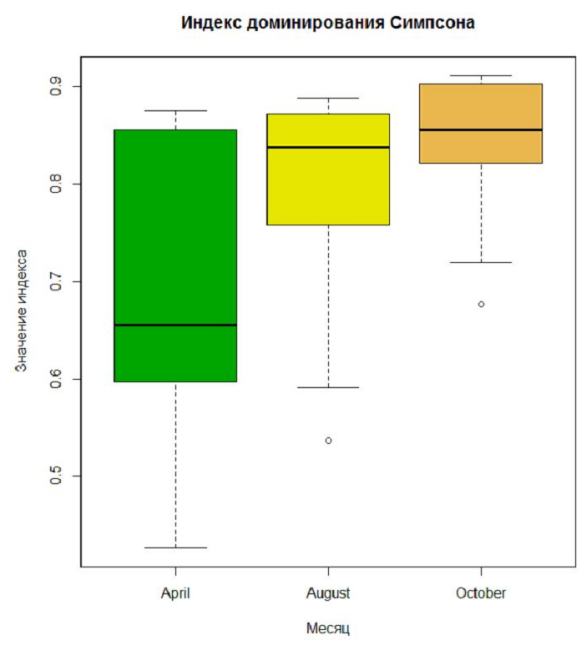

с) Индекс доминирования Симпсона

Рис. 4. Диаграммы размахов значений индексов 
Оценка состояния водоемов поймы по различным показателям зообентоса

Таблийа 2

Бальные шкалы оценки показателей состояния зооценозов бентоса в водоемах Волго-Ахтубинской поймы

\begin{tabular}{|c|c|c|c|}
\hline Баллы & Апрель & Август & Октябрь \\
\hline \multicolumn{4}{|c|}{ Значения численности } \\
\hline 1 & $0-281$ & $0-673$ & $0-502$ \\
\hline 2 & $282-728$ & $674-796$ & $503-1790$ \\
\hline 3 & $729-1357$ & $797-1199$ & $1791-4432$ \\
\hline 4 & $1358-2563$ & $1200-1559$ & $4433-4811$ \\
\hline 5 & $>2564$ & $>1560$ & $>4812$ \\
\hline \multicolumn{4}{|c|}{ Значениям биомассы } \\
\hline 1 & $0-1,228$ & $0-0,848$ & $0-1,885$ \\
\hline 2 & $1,229-3,301$ & $0,849-1,360$ & $1,886-2,931$ \\
\hline 3 & $3,302-10,401$ & $1,361-3,072$ & $2,932-11,793$ \\
\hline 4 & $10,402-14,756$ & $3,073-3,925$ & $11,794-14,959$ \\
\hline 5 & $>14,757$ & $>3,926$ & $>14,960$ \\
\hline \multicolumn{4}{|c|}{ Количество видов } \\
\hline 1 & $0-4$ & $0-10$ & $0-12$ \\
\hline 2 & $5-8$ & $11-13$ & $13-14$ \\
\hline 3 & $9-12$ & $14-15$ & $15-19$ \\
\hline 4 & $13-15$ & $16-18$ & $20-26$ \\
\hline 5 & $>15$ & $>18$ & $>26$ \\
\hline \multicolumn{4}{|c|}{ Индекс Шеннона } \\
\hline 1 & $<0,955$ & $<1,281$ & $<1,772$ \\
\hline 2 & $0,955-1,269$ & $1,281-1,683$ & $1,772-1,954$ \\
\hline 3 & $1,270-1,395$ & $1,684-2,111$ & $1,955-2,119$ \\
\hline 4 & $1,396-2,090$ & $2,112-2,260$ & $2,120-2,583$ \\
\hline 5 & $>2,091$ & $>2,261$ & $>2,584$ \\
\hline \multicolumn{4}{|c|}{ Индекса выровненности по Шеннону } \\
\hline 1 & $<0,431$ & $<0,514$ & $<0,502$ \\
\hline 2 & $0,431-0,561$ & $0,514-0,621$ & $0,502-0,705$ \\
\hline 3 & $0,562-0,671$ & $0,622-0,766$ & $0,706-0,765$ \\
\hline 4 & $0,672-0,825$ & $0,767-0,851$ & $0,766-0,813$ \\
\hline 5 & $>0,826$ & $>0,852$ & $>0,814$ \\
\hline \multicolumn{4}{|c|}{ Индекса доминирования Симпсона } \\
\hline 1 & $>0,854$ & $>0,865$ & $>0,903$ \\
\hline 2 & $0,645-0,854$ & $0,830-0,865$ & $0,851-0,903$ \\
\hline 3 & $0,586-0,644$ & $0,707-0,829$ & $0,818-0,850$ \\
\hline 4 & $0,427-0,585$ & $0,538-0,706$ & $0,678-0,817$ \\
\hline 5 & $<0,426$ & $<0,537$ & $<0,677$ \\
\hline
\end{tabular}

Таблииа 3

Балльная оценка состояния зообентоса в водоемах Волго-Ахтубинской поймы за вегетационный период

\begin{tabular}{|c|c|c|c|c|}
\hline Водный объект & Весна & Лето & Осень & Всего \\
\hline Озеро Бессчастное & 18 & 15 & 14 & 47 \\
\hline Озеро Чичера & 19 & 19 & 17 & 55 \\
\hline Озеро Дубок & 25 & 18 & 23 & 66 \\
\hline Озеро Боярский лиман & 23 & 22 & 15 & 60 \\
\hline Ерик Калинов & 14 & 21 & 21 & 56 \\
\hline Озеро Кудаевское & 23 & 21 & 23 & 67 \\
\hline Ерик Старая Ахтуба & 15 & 17 & 15 & 47 \\
\hline Ерик Гнилой & 18 & 24 & 21 & 63 \\
\hline Озеро Дегтярное & 19 & 21 & 24 & 64 \\
\hline Озеро Запорное & 21 & 22 & 22 & 65 \\
\hline Озеро Большая Невидимка & 21 & 17 & 20 & 58 \\
\hline Озеро Широкогорлое & 24 & 20 & 21 & 65 \\
\hline
\end{tabular}




\section{ЭКОЛОГИЯ И ПРИРОДОПОЛЬЗОВАНИЕ}

Интервал колебаний весенней суммарной балльной оценки изменяется в пределах от 14 (Ерик Калинов) до 25 (Озеро Дубок). Среднее значение для 12 водоемов составляет 20 баллов. Половина исследуемых водоемов находится в интервалах, превышающих среднее значение балльной оценки, то есть можно считать, что их структура и состояние находится в пределах нормы. Остальные водоемы находятся в интервалах ниже среднего значения, что позволяет говорить о влиянии на ценозы антропогенных или естественных негативных воздействий.

Интервал летней суммарной балльной оценки изменяется в пределах от 15 (Озеро Бессчастное) до 24 (Ерик Гнилой). Среднее значение по 12 водоемам составляет 19,75 балла. Семь из двенадцати водоемов находится в интервалах, превышающих среднее значение балльной оценки, т.е. можно считать, что структура и состояние водоемов находятся в пределах нормы. Пять водоемов имеют показатели в интервалах ниже среднего значения, что позволяет говорить о наличии пресса антропогенного или естественного происхождения.

Интервал осенней суммарной балльной оценки находится в пределах от 14 (Озеро Бессчастное) до 24 (Озеро Дегтярное), составляя в среднем по 12 водоемам 19,6 баллов. Восемь из двенадцати водоемов имеют оценку превышающую среднее значение, что говорит о нормальной структуре и стабильном состоянии водоемов. Четыре озера находятся в интервалах ниже среднего значения, что позволяет говорить о естественном негативном или антропогенном воздействии.

В среднем баллы по сезонам одинаковые, что может быть связано с тем, что несмотря на периодически стрессовые условия (полное или частичное обсыхание и промерзание) донные биоценозы достаточно быстро восстанавливаются.

Заключение. Проведенная оценка состояния 12 водоемов Волго-Ахтубинской поймы показала, что озеро Широкогорлое, Запорное и Кудаевское на протяжении вегетационного периода имеют нормальную структуру. А ерик Старая Ахтуба, озеро Бессчастное и Чичера подвержены влиянию антропогенных или естественных негативных воздействий на протяжении года. Ерик Калинов, Гнилой и озеро Дегтярное в весенний сезон подвергаются негативному влиянию, а к летнему и осеннему периоду их состояние стабилизируется. Состояние озер Дубок и Большая Невидимка весной и осенью находится в пределах нормы, а летом, наоборот, подвергается воздействию. Озеро Боярский лиман в весенний и летний период имеет нормальную структуру, а осенью его состояние ухудшается. Такая вариация состояния, по всей видимости возникает по вышеназванным причинам (период размножения, цикличность развития зообентоса, интенсивное выедание организмов рыбой, особенности гидрологического режима).

\section{СПИСОК ЛИТЕРАТУРЫ}

1. Безматерных, Д. М. Зообентос как индикатор экологического состояния водных экосистем Западной Сибири : аналит. обзор / Д. М. Безматерных. - Новосибирск : Гос. публич. науч.-техн. б-ка Сиб. отд-ния Рос. акад. наук, Ин-т вод, и экол. проблем, 2007. $-87 \mathrm{c}$.

2. Брылев, В. А. Родники и реки Волгоградской области : монография / В. А. Брылев, Н. А. Самусь, Е. Н. Славгородская. - Волгоград : Михаил, 2007. $-200 \mathrm{c}$.

3. Волго-Ахтубинская пойма - природный дар человечеству : иллюстр. науч.-популяр. очерк по охране природы / науч. ред. и сост. В. В. Малыченко ; под общ. ред. В. Ф. Желтобрюхова и И. М. Шабуниной. - Волгоград : Издатель, 2006. $472 \mathrm{c}$.

4. Гольд, 3. М. Общая гидробиология : учеб.метод. пособие / 3. М. Гольд. - 2-е изд., перераб. Красноярск : Сиб. федерал. ун-т, 2013. - 158 с.

5. Горелов, В. П. Восстановление биоразнообразия донных биоценозов водоемов Волго-Ахтубинской поймы в экстремальных условиях пересыхания и промерзания / В. П. Горелов // ООПТ Нижней Волги как важнейший механизм сохранения биоразнообразия: итоги, проблемы и перспективы : материалы науч.-практ. конф. - Волгоград : [б. и.], 2010. - С. 68-73.

6. Горелов, В. П. Интенсивность развития и продукция хирономид в водоемах Волго-Ахтубинской поймы // Межотраслевая науч.-практ. конф. «Состояние и охрана биологических ресурсов Волгоградской области». - Волгоград : [б. и.], 1981. С. $75-76$.

7. Горелов, В. П. Характеристика донной фауны водоемов Волго-Ахтубинской поймы как кормо- 
вой базы рыб / В. П. Горелов // Природный парк «Волго-Ахтубинская пойма». Природно-ресурсный потенциал : науч. сб. - Волгоград : [б. и.], 2004. - С. 105-117.

8. Горелов, В. П. Водные беспозвоночные / В.П. Горелов // Природные комплексы и биоразнообразие долины Нижней Волги : учеб. пособие. Волгоград, 2011. - С. 114-121.

9. Горелов, В. П. Донная кормовая база водоемов Волго-Ахтубинской поймы // Материалы Междунар. конф. «Мелиорация малых водотоков, нерестилищ дельты р. Волги и Волго-Ахтубинской поймы». - Астрахань : ЦНТЭП, 2007. - С. 64-66.

10. Даирова, Д. С. Современное состояние макрозообентоса в мониторинге водотоков дельты p. Волги и Волго-Ахтубинской поймы : автореф. дис. ... канд. биол. наук / Даирова Динара Сруровна. - Тольятти, 2004. - 20 с.

11. Клинкова, Г. Ю. Комплексные индикаторы состояния биоразнообразия водно-болотных угодий / Г. Ю. Клинкова, В. П. Горелов, Л. Г. Волынова // ООПТ Нижней Волги как важнейший механизм сохранения биоразнообразия: итоги, проблемы и перспективы : материалы науч.-практ. конф. Волгоград : [б. и.], 2010. - С. 126-135.

12. Константинов, А. С. Бентос Волги близ Саратова и влияние на него загрязнения / А. С. Константинов // Труды Саратовского отделения Каспийского филиала ВНИРО. - 1953. - Т. 2. - С. 72-89.

13. Ляхов, С. М. Материалы по донному населению Волги от Рыбинска до Астрахани к началу ее гидротехнической реконструкции // Труды института биологии водохранилищ. - 1961. - Вып. 4 (7). C. 187-203.

14. Мастицкий, С. Э. Статистический анализ и визуализация данных с помощью R. / C. Э. Мастицкий, В. К. Шитиков. - Электрон. текстовые дан. Режим доступа: http://r-analytics.blogspot.com. Загл. с экрана.

15. Рыбохозяйственная оценка кормовой базы водоемов Волго-Ахтубинской поймы в условиях зарегулированного стока Волги / М.П. Мирошниченко [и др.] // Состояние и охрана биологических ресурсов Волгоградской области : тез. докл. 2-й межотрасл. науч.-практ. конф. - Волгоград : [б. и.], 1981. - С. 64-116.

16. Определитель пресноводных беспозвоночных Европейской части СССР / под ред. Л. А. Кутикова, Я. И. Старобогатова. - Л. : Гидрометеоиздат, 1977. $-512 \mathrm{c}$.

17. Панкратова, В. Я. Личинки и куколки комаров подсемейства Podonominae и Tanypodinae фауны СССР / В. Я. Панкратова. - Ленинград : Наука, 1977. $-153 \mathrm{c.}$

18. Панкратова, В. Я. Личинки и куколки комаров подсемейства Chironominae фауны CCCP / В. Я. Панкратова. - Ленинград : Наука, 1977. - 296 с.
19. Панкратова, В. Я. Личинки и куколки комаров подсемейства Orthocladiinae фауны СССР / В. Я. Панкратова. - Ленинград : Наука, 1977. $344 \mathrm{c}$.

20. Руководство по гидробиологическому мониторингу пресноводных экосистем / под ред. проф. В. А. Абакумова. СПб. : [б. и.], 1993. - 320 с.

21. Шилова, А. И. Хирономиды Рыбинского водохранилища / А. И. Шилова. - Л. : Наука, 1976. $251 \mathrm{c}$.

22. Shannon, C. E. The Mathematical Theory of Communication / C. E. Shannon, W. Weaver. - Urbana : The University of Illinois Press, 1963.-117 p.

23. Wustemann, O. Gewassergutebtstimmung Mittels Indicatoren Organismen / O. Wustemann // Zeitschrift fur die Binnenfischerei der DDR. Berlin. 1989. - № 9. - P. 250-258.

\section{REFERENCES}

1. Bezmaterny D.M. Zoobentos kak indikator jekologicheskogo sostojanija vodnyh jekosistem Zapadnoj Sibiri: analit. obzor [Zoobentos as an Indicator of Water Ecosystems State in Western Siberia]. Novosibirsk, Gos. publich. nauch.-tehn. b-ka Sib. otd-nija Ros. akad. nauk, In-t vod, i jekol. problem, 2007.87 p.

2. Brylyov V.A. Samus N. A., Slavgorodskaja E. N. Rodniki i reki Volgogradskoj oblasti [ Springs and Rivers of the Volgograd Region]. Volgograd, Mihail, 2007. 200 p.

3. Volgo-Ahtubinskaja pojma - prirodnyj dar chelovechestvu: Illjustr. nauch.-populjar. ocherk po ohrane prirody [Volga-Akhtuba Floodplain - a Natural Gift to Humanity]. Volgograd, Izdatel, 2006. 472 p.

4. Gold Z.M., Gold V.M. Obshhaja gidrobiologija: uchebno-metodicheskoe posobie [General Hydrobiology: Educational-Methodical Manual]. Krasnojarsk, Sib. federal. un-t, 2013. 158 p.

5. Gorelov V.P. Vosstanovlenie bioraznoobrazija donnyh biocenozov vodoemov Volgo-Ahtubinskoj pojmy $\mathrm{v}$ jekstremalnyh uslovijah peresyhanija $\mathrm{i}$ promerzanija [The Restoration of Biodiversity of Bottom Biocenoses of Water Bodies of the VolgaAkhtuba Floodplain Under Extreme Conditions of Drying and Freezing] OOPT Nizhnej Volgi kak vazhnejshij mehanizm sohranenija bioraznoobrazija: itogi, problemy i perspektivy: materialy nauch.-prakt. konf. [Protected Areas of the Lower Volga as the Most Important Mechanism for Biodiversity Conservation: Results, Problems and Prospects: Materials of a Scientific and Practical Conference]. Volgograd, 2010, pp. 68-73.

6. Gorelov V.P. Intensivnost razvitija i produkcija hironomid v vodoemah Volgo-Ahtubinskoj pojmy [Intensity of Development and Production of 


\section{ЭКОЛОГИЯ И ПРИРОДОПОЛЬЗОВАНИЕ}

Chironomids in Reservoirs of the Volga-Akhtuba Floodplain]. Mezhotraslevaja nauch.-prakt. konf. "Sostojanie i ohrana biologicheskih resursov Volgogradskoj oblasti» [Intersectoral Scientific and Practical. Conf. "The State and Protection of Biological Resources of the Volgograd Region”]. Volgograd, 1981. pp. 75-76.

7. Gorelov V.P. Harakteristika donnoj fauny vodojomov Volgo-Ahtubinskoj pojmy kak kormovoj bazy ryb. [Characterization of the Bottom Fauna of the Volga-Akhtuba Floodplain as a Food Base for Fish]. Prirodnyj park "Volgo-Ahtubinskaja pojma”. Prirodno-resursnyj potencial: nauch. sb. Volgograd, 2004,pp. 105-117.

8. Gorelov V.P. Vodnye bespozvonochnye [Aquatic invertebrates]. Prirodnye kompleksy $i$ bioraznoobrazie doliny Nizhnej Volgi: ucheb. posobie. Volgograd, 2011, pp. 114-121.

9. Gorelov V.P. Donnaja kormovaja baza vodojomov Volgo-Ahtubinskoj pojmy [Bottom Feed Base of the Volga-Akhtuba Floodplain]. Materialy mezhdunarodnoj konferencii "Melioracija malyh vodotokov, nerestilishh del'ty r. Volgi i VolgoAhtubinskoj pojmy" [Materials of the International Conference "Reclamation of Small Watercourses, Spawning Grounds of the Volga River Delta and the Volga-Akhtuba Floodplain]. Astrahan, CNTJeP, 2007, pp. 64-66.

10. Dairova D.S. Sovremennoe sostojanie makrozoobentosa $v$ monitoringe vodotokov del'ty $r$. Volgi i Volgo-Ahtubinskoj pojmy: avtoref. dis. ... cand. bio. nauk [The Current State of Macrozoobenthos in Monitoring the Delta River Watercourses Volga and Volga-Akhtuba Floodplain]. Tolyatti, 2004. 20 p.

11. Klinkova G.Ju., Gorelov V.P., Volynova L.G. Kompleksnye indikatory sostojanija bioraznoobrazija vodno-bolotnyh ugodij [Comprehensive Indicators of the Status of Wetland Biodiversity.]. OOPT Nizhnej Volgi kak vazhnejshij mehanizm sohranenija bioraznoobrazija: itogi, problemy i perspektivy: materialy nauchno-prakticheskoj konferencii. [Protected Areas of the Lower Volga as the Most Important Mechanism for the Conservation of Biodiversity: Results, Problems and Prospects: Materials of a Scientific and Practical Conference]. Volgograd, 2010, pp. 126-135.

12. Konstantinov A.S. Bentos Volgi bliz Saratova i vlijanie na nego zagrjaznenija [Bentos Volga Near Saratov and the Effect of Pollution on it]. Trudy
Saratovskogo otdelenija Kaspijskogo filiala VNIRO. 1953, vol. 2, pp. 72-89.

13. Ljahov S.M. Materialy po donnomu naseleniju Volgi ot Rybinska do Astrahani k nachalu ee gidrotehnicheskoj rekonstrukcii [Materials on the Bottom Population of the Volga from Rybinsk to Astrakhan to the Beginning of its Hydrotechnical Reconstruction] // Trudy instituta biologii vodohranilishh [Proceedings of the Institute of Reservoir Biology], 1961. vol. 4 (7). pp. 187-203.

14. Mastitsky S.Je., Shitikov V.K. Statisticheskij analiz $i$ vizualizacija dannyh s pomoshh'ju $R$. [Statistical Analysis and Visualization of Data Using R]. URL: http://r-analytics.blogspot.com.

15. Miroshnichenko M.P., Glamazda V.V., Kalinina S.G., et al. Rybohozjajstvennaja ocenka kormovoj bazy vodojomov Volgo-Ahtubinskoj pojmy v uslovijah zaregulirovannogo stoka Volgi [Fisheries Assessment of the Forage Base of Water Bodies of the VolgaAkhtuba Floodplain in the Conditions of Regulated Volga Runoff]. Sostojanie i ohrana biologicheskih resursov Volgogradskoj oblasti: tezisy dokladov 2-y mezhotraslevoj nauchno-prakticheskoj konferencii [The State and Protection of Biological Resources of the Volgograd Region (Abstracts of the $2^{\text {nd }}$ Interbranch Scientific and Practical Conference)]. Volgograd, 1981, pp. 64-116.

16. Key to Freshwater Invertebrates in the European Part of the USSR. Leningrad, 1977.

17. Pankratova V.Ya. Larvae and Pupae of Mosquitoes of the Subfamily Podonominae and Tanypodinae of the Fauna of the USSR. Leningrad, Nauka, 1970. $153 \mathrm{p}$.

18. Pankratova V.Ya. Larvae and Pupae of Mosquitoes of the Subfamily Chironominae of the Fauna of the USSR. Leningrad, Nauka, 1970.296 p.

19. Pankratova V.Ja. Larvae and Pupae of Mosquitoes of the Subfamily Orthocladiinae of the Fauna of the USSR. Leningrad, Nauka, 1970.344 p.

20. Guidelines for Hydrobiological Monitoring of Freshwater Ecosystems. SPb., 1993. 320 p.

21. Shilova A.I. Chironomids of the Rybinsk Reservoir. Leningrad, Nauka, 1976. 251 p.

22. Shannon C.E. The Mathematical Theory of Communication. Urbana, The University of Illinois Press, 1963. $117 \mathrm{p}$.

23. Wustemann O. Gewassergutebtstimmung Mittels Indicatoren Organismen. Zeitschrift fur die Binnenfischerei der DDR, 1989, no. 9. pp. 250-258. 


\section{Information About the Authors}

Angelina M. Schukina,Student, Department of Biology, Volgograd State University, Prosp. Universitetsky, 100, 400062 Volgograd, Russian Federation; Junior Specialist, Department of Hydrobiology, Volgograd branch of Russian Federal Research Institute of Fisheriesand Oceanography, Pugachevskaya St., 1, 400001 Volgograd, Russian Federation, L_gela97@mail.ru.

Vladimir P. Gorelov, Head of the Department of Hydrobiology, Volgograd branch of Russian Federal Research Institute of Fisheriesand Oceanography, Pugachevskaya St., 1, 400001 Volgograd, Russian Federation, vladimirgorelov@yandex.ru, gidrobiologiavo@mail.ru.

Tatjana E. Zenkina, Head of Ecological Department, LLC "Volgogradnefteproekt”, Lesogorskaya St., 85a, 400048 Volgograd, Russian Federation; Senior Lecturer, Department of Biology, Volgograd State University, Prosp. Universitetsky, 100, 400062 Volgograd, Russian Federation, tatyanaez@mail.ru, zenkina@volsu.ru.

\section{Информация об авторах}

Ангелина Михайловна Щукина, студентка кафедры биологии, Волгоградский государственный университет, просп. Университетский, 100, 400062 г. Волгоград, Российская Федерация; младший специалист отдела Гидробиологии, Волгоградский филиал Всероссийского научноисследовательского института рыбного хозяйства и океанографии, ул. Пугачевская, 1, 400001 г. Волгоград, Российская Федерация, L_gela97@mail.ru.

Владимир Павлович Горелов, заведующий отдела Гидробиологии, Волгоградский филиал Всероссийского научно-исследовательского института рыбного хозяйства и океанографии, ул. Пугачевская, 1, 400001, г. Волгоград, Российская Федерация, vladimirgorelov@yandex.ru, gidrobiologiavo@mail.ru.

Татьяна Евгеньевна Зенкина, начальник отдела экологии, ООО «Волгограднефтепроект», ул. Лесогорская, 85a, 400048 г. Волгоград, Российская Федерация; старший преподаватель кафедры биологии, Волгоградский государственный университет, просп. Университетский, 100, 400062 г. Волгоград, Российская Федерация, tatyanaez@mail.ru, zenkina@volsu.ru. 